\title{
THE PHENOMENON OF STUDENT MIGRATION IN UKRAINE
}

${ }^{\odot} 2020$ VELYCHKO K. YU., YAREMENKO M. 0.

UDC 314.74

JEL: F22

\section{Velychko K. Yu., Yaremenko M. O. The Phenomenon of Student Migration in Ukraine}

To study the processes of educational migration among Ukrainian students, in the article, the features of the process of student migration in Ukraine were analyzed. Factors that significantly influence this process were highlighted, among which the main one is the desire to get a good education because of the higher standards and, most often, to stay after studying in a country, which altogether is negative for Ukraine. It was determined that the main impetus for expanding educational migration was the adoption in 2014 of the Law of Ukraine "On Higher Education", that declared international integration and integration of the national higher education system into the European educational space, as well as an active participation of Ukrainian universities in Erasmust, Horizon 2020, which formed a segment of Ukrainian international academic mobility. Using scientific methods such as data collection, interpretation of research, and construction of several regression models, it was concluded that Poland, Germany, and the Russian Federation are the centers of attraction of Ukrainian student youth during the study period. It was proved that the factors which contributed to the selection of these countries are linguistic and territorial proximity (Russia, Poland), perception of tradition, culture, as well as the opportunity to study for free (France, Poland). It was also emphasized the importance of the gender aspect of student migration. It was statistically proven that women are more likely to go abroad for tertiary education than men. Using a model of multiple regression, which was not previously used in studies of migration processes, it was found that among the possible factors influencing the variable "exit mobility rate", the development of international tourism had the greatest impact. Necessary migration policy measures on reducing the level of emigration were proposed. Moreover, the importance of solving such a problem as "brain drain" was suggested, which means the emigration of highly qualified professionals, associated with student migration, and has a very negative impact on the formation of scientific potential, and the recommendations to eliminate the negative results of the current situation of "brain drain" in Ukraine were proposed. Furthermore, the mentioned in this article scientific developments can be used in further research on student emigration in Ukraine.

Keywords: emigration, education, student migration, factors of migration, academic mobility.

DOl: $h$ https://doi.org/10.32983/2222-4459-2020-5-62-70

Fig.: 5. Tabl.: 3. Bibl.: 10.

Velychko Kateryna Yu. - PhD (Economics), Associate Professor of the Department of International Economics and Management FEA, Simon Kuznets Kharkiv National University of Economics (9a Nauky Ave., Kharkiv, 61166, Ukraine)

E-mail: eklevyna@gmail.com

ORCID: https://orcid.org/0000-0002-7751-585X

Researcher ID: $h$ ttt://www.researcherid.com/rid/B-1738-2019

Yaremenko Mariia O. - Student, Faculty of International Economic Relations, Simon Kuznets Kharkiv National University of Economics (9a Nauky Ave., Kharkiv, 61166, Ukraine)

E-mail: yarmar525@gmail.com

ORCID: https://orcid.org/0000-0002-9336-0202

УДК 314.74

JEL: F22

Величко К. Ю., Яременко М. О. Феномен студентської міграції в Україні

3 метою дослідження процесів освітньої міграції серед українських студентів у статті було проаналізовано особливості процесу міграції студентської молоді в Україні. Виділено фактори, які суттєво впливають на чей процес, серед яких ключовим $є$ бажання одержати гарну освіту за більш високими стандартами та, найчастіше, залишитися після навчання у країні, що є негативним для України. Визначено, що головним поштовхом для розширення освітньої міграції було ухвалення у 2014 р. Закону України «Про вищу освіту», де декларується міннародна інтеграція та інтеграція національної системи вищої освіти до європейського освітнього простору, а також активна участь українських університетів у програмах Еразмус+, Горизонт-2020, що фактично сформувало сегмент української міннародної академічної мобільності. Використовуючи наукові методи, такі як збирання даних, інтерпретація досліджень і побудова декількох моделей регресії, було зроблено висновки, що Польща, Німеччина, Російська Федерація виступають центрами тяжіння студентської молоді з України впродовж досліджуваного періоду. Доведено, що факторами, які сприяли виділенню цих країн, є мовна та територіальна близькість (Росія, Польща), сприйняття традицій, культури, а також можливість навчання на безоплатній основі (Франція, Польща). Акцентовано увагу і на гендерному аспекті студентської міграції. Статистично доведено, що жінки частіше їуть за кордон для отримання вищої освіти, ніж чоловіки. завдяки моделі множинної регресії, яка раніше не застосовувалася в дослідженнях міграційних процесів, було з'ясовано, що серед можливих факторів, що впливають на змінний «коеріцієнт виїзної мобільності», найбільший вплив мав розвиток міжнародного туризму. Запропоновано необхідні заходи міграційної політики щодо зниження рівня еміграції. Крім того, наголошено на важливості вирішення такої проблеми, як «відтік мізків», тобто еміграції висококваліфікованих фахівців, що пов'язано також зі студентською міграцію та вкрай негативно відбивається на формуванні наукового потенціалу країни. Надано рекомендації щодо усунення негативних результатів нинішньої ситуації «відтоку мізків» з України. Запропоновані наукові розробки можуть бути використані в подальших дослідженнях проблематики студентської еміграції в Україні.

Ключові слова: міграція, студентська міграція, освіта, фактори міграції, академічна мобільність.

Рис.: 5. Табл.: 3. Бібл.: 10.

Величко Катерина Юріївна - кандидат економічних наук, доцент кафедри міжнародної економіки та менеджменту зЕД, Харківський національний економічний університет ім. С. Кузнеия (просп. Науки, 9а, Харків, 61166, Україна)

E-mail: eklevyna@gmail.com

ORCID: https://orcid.org/0000-0002-7751-585X

Researcher ID: http://www.researcherid.com/rid/B-1738-2019 
Яременко Марія Олександрівна - студентка факультету міжнародних економічних відносин, Харківський національний економічний університет ім. С. Кузнеия (просп. Науки, 9а, Харків, 61166, Україна)

E-mail:yarmar525@gmail.com

ORCID: https://orcid.org/0000-0002-9336-0202

УДК 314.74

JEL: F22

Величко Е. Ю., Яременко М. А. Феномен студенческой миграции в Украине

С целью исследования процессов образовательной миграции среди украинских студентов в статье проанализированы особенности процесса миграции студенческой молодежи в Украине. Выделены факторы, которые существенно влияют на этот процесс, среди которых ключевым является желание получить хорошее образование по высоким стандартам и, чаще всего, остаться после учебы в стране, что является негатив-

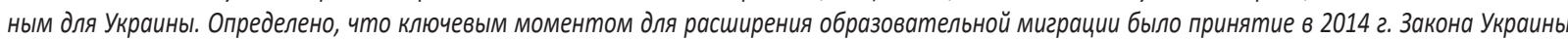
"О высшем образовании», где декларируется международная интеграция и интеграция национальной системы высшего образования в европейское образовательное пространство, а также активное участие украинских университетов в программах Эразмус+, Горизонт-2020, что фрактически сформировало сегмент украинской международной академической мобильности. Используя научные методы, такие как сбор данных, интерпретация исследований и построение нескольких моделей регрессии, были сделаны выводы, что Польша, Германия, Российская Федерация выступают центрами притяжения студенческой молодежи из Украины в исследуемом периоде. Доказано, что факторами, способствовавшими выделению этих стран, являются языковая и территориальная близость (Россия, Польша), принятие традиций, культуры, а также возможность бесплатного обучения (Франция, Польша). Акцентировано внимание и на гендерном аспекте студенческой миграции. Статистически доказано, что женщины чаще едут для получения высшего образования, чем мужчины. Благодаря модели множественной регрессии, которая ранее не применялась в исследованиях миграционных процессов, было выяснено, что среди возможных факторов, влияющих на переменный «коэффициент выездной мобильности», наибольшее влияние имело развитие международного туризма. Предложены необходимые меры миграционной политики по снижению уровня эмиграции. Кроме того, отмечается важность решения такой проблемы, как "утечка мозгов», то есть эмиграции высококвалифицированных специалистов, что связано и со студенческой миграцией и крайне негативно отражается на формировании научного потенциала страны. Даны рекомендации по устранению негативных результатов нынешней ситуации «утечки мозгов» из Украины. Предложенные научные разработки могут быть использованы в дальнейших исследованиях проблематики студенческой эмиграции в Украине. Ключевые слова: миграция, студенческая миграция, образование, факторы миграции, академическая мобильность.

Рис.: 5. Табл.: 3. Библ.: 10.

Величко Екатерина Юрьевна - кандидат экономических наук, доцент кафедры международной экономики и менеджмента ВэД, Харьковский национальный экономический университет им. С. Кузнеца (просп. Науки, 9а, Харьков, 61166, Украина)

E-mail: eklevyna@gmail.com

ORCID: https://orcid.org/0000-0002-7751-585X

Researcher ID: http://www.researcherid.com/rid/B-1738-2019

Яременко Мария Александровна - студентка факультета международных экономических отношений, Харьковский национальный экономический университет им. С. Кузнеца (просп. Науки, 9а, Харьков, 61166, Украина)

E-mail: yarmar525@gmail.com

ORCID: https://orcid.org/0000-0002-9336-0202

$\mathrm{T}$ The student population is one of the most valuable human resources of a nation and its most mobile socio-demographic segment, which tends to migrate within the country or abroad. Nowadays, globalization tendencies are affecting many nations, and Ukraine is not an exceptional case in the context of migration.

The integration of international economic relations is influencing the development of the actual international labor market, contributing to the strengthening of population inflow/outflow processes. It is the transformations of social and economic relations that are taking place around the world under the impact of globalization. The financial and economic instability of countries, political and security threats, and military conflicts significantly increase the scope and intensity of migration. Therefore, multifactorial migration processes, complex connections with economic, demographic, political, cultural, and other phenomena require profound research.

The problem of migration is one of the most pressing ones in Ukraine today. A significant place, after the labor and domestic migration, is taken by student migration, the level of which is increasing from year to year. The majority of migrating students are seeking the education of bet- ter quality in foreign universities and colleges. On the one hand, taking into consideration the fact that the conditions of the modern economy are closely connected with world internationalization, it is the knowledge that can be used in innovations, which is aimed to boost the wealth of an individual or a country as a whole. Nevertheless, on the other hand, for a particular nation, educational migration may cause a significant loss of potential labor force.

For the territories from which the youth is migrating, there is a serious question that inevitably emerges. It concerns the perspectives of their development because the flow of human resources will inevitably affect less developed regions.

The complexity of the phenomenon of student migration has been studied by both Ukrainian and Russian scientists - K. Brenzovych, V. Filatov, D. Kiryukhin, V. Iontsev, O. Malynovska, O. Sytnyk, O. Slobodian, L. Zhurakovska - and foreign researchers - F. Docquier, A. Marfouk, C. Dustmann, A. Glitz, H. Hazen, P. Raghuram, E. Baryla , Jr, D. Dotterweich, and others.

Even though a large number of important aspects of international migration have been reflected in scientific works, factors that influence the current trends in 
student migration processes in Ukraine require further analysis.

The aim of the research work is to study the modern specificity of educational migration processes in Ukraine, factors affecting them, consequences of the increased migration flows, and development of necessary migration policy measures to reduce the level of migration.

$\mathrm{T}$ he problem of external labor migration is extremely important for Ukraine at this stage. The sharp increase in the number of Ukrainian migrants abroad and the related socio-economic and demographic problems are on the agenda both at the regional and national levels. The situation was made more pressing with the visa liberalization with the EU countries obtained by Ukraine in 2014.

It is worth paying attention to the fact that women are more likely to migrate than men. This is proved by the statistical data taken from the State Statistics Service of Ukraine, which can be found in the diagram below (Fig. 1).

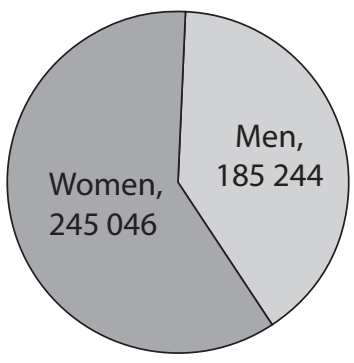

Fig. 1. The number and percentage of the Ukrainian people who migrated, by sex, 2017 [9]

The Fig. 1 perfectly describes that $57 \%$ of women are prone to relocation. These figures include both regional migration and international one. According to the United Nations Population Division, at the end of the 20th century, the flow of migrant women was growing at a faster rate than that of men in countries that were the most frequent recipients of expats. The new trend of feminization of international migration emerged, which was a consequence of modern changes in the structure of employment and segmentation of the world labor market. For a long time, researches on migration processes have suggested that the vast majority of migrant workers are represented by men who are the breadwinners of families, while women are responsible for their children and housework. Traditionally, women have not been considered as subjects of migration at all or considered as "dependent" and migrants accompanying their family or husband. In particular, the main features of the transformation in migration processes related to gender issues include the following trends:

+ feminization of international migration - accelerated growth in the number and proportion of women in international migrants;
+ change in the role of women in the family, society, economy;

+ gender segmentation of the international labor market;

+ increased vulnerability of migrant women to discrimination, exploitation, and violation of human rights, including trafficking in human beings.

The number of migrants has also been studied in the context of age (Tbl. 1).

Table 1

The number of migrants in Ukraine (regional and international) in 2017 [9]

\begin{tabular}{|c|c|c|c|}
\hline Age & Both sexes & Men & Women \\
\hline Total & 430290 & 185244 & 245046 \\
\hline $0-4$ & 23732 & 12007 & 11725 \\
\hline $5-9$ & 18970 & 9719 & 9251 \\
\hline $10-14$ & 12548 & 6342 & 6206 \\
\hline $15-19$ & 70735 & 31157 & 39578 \\
\hline $20-24$ & 69336 & 31022 & 38314 \\
\hline $25-29$ & 45630 & 16972 & 28658 \\
\hline $30-34$ & 40030 & 14265 & 25765 \\
\hline $35-39$ & 28737 & 11851 & 16886 \\
\hline $40-44$ & 21473 & 9806 & 11667 \\
\hline $45-49$ & 16888 & 8032 & 8856 \\
\hline $50-54$ & 15757 & 7370 & 8387 \\
\hline $55-59$ & 17964 & 7915 & 10049 \\
\hline $60-64$ & 16886 & 7594 & 9292 \\
\hline $65-69$ & 12331 & 5098 & 7233 \\
\hline $70-74$ & 6006 & 2248 & 3758 \\
\hline $75-79$ & 6959 & 2198 & 4761 \\
\hline $80-84$ & 3711 & 1040 & 2671 \\
\hline 85 and older & 2597 & 608 & 1989 \\
\hline
\end{tabular}

$\square$ rom the table above we can discern 2 main groups of those migrating: female teenagers aged 15-19 account for $16.15 \%$, and the same layer but male $16.82 \%$ of migrants; female adolescents aged 20-24 account for $15.63 \%$, and male adolescents $-16.74 \%$.

It is evident that the youth is taking the biggest share in the migration. A decrease in the average age of migrants provokes problems of an aging nation, decline in the birth rate, deterioration in the labor potential of the population, etc.

These results can also describe the psychological and sociological aspects of migration. Not having stable employment or attachment to certain social groups or their environment yet, young people are seeking a new experience in their life. That is why, for them, it is possible to search for better lifestyles with minimal losses. Women are proven to be more likely to migrate than men. It can be explained by their psychological nature, will to explore new horizons, whereas men are more 
down-to-earth and practical, wishing to build their future in one place.

It is worth highlighting that a significant problem in studying the actual course of migration processes, their quantitative and qualitative measurement is the inability to form a realistic estimate of the structure of migration flows from Ukraine in connection with a significant sector of shadow and irregular migration.

Obviously, being immature, this age group of youth is not generally searching for workplaces when going abroad. Their main reason is the opportunity to enroll in foreign universities and to get higher education there.

$\mathrm{W}$ e share the view of $\mathrm{V}$. Iontsev, who defines educational migration as a territorial movement from one location to another with the purpose to study in one of the educational institutions of another location. Upon completion of the study, the person who went to another country is obliged to return home. However, there are cases of non-return, which are classified as brain drain [3]. This phenomenon is highly relevant for Ukraine's reality nowadays. We also agree with the definition given by O. Malynovska: international education migration is the moving of foreign students [4].

The key impetus for the expansion and intensification of educational migration was the adoption of the Law of Ukraine "On Higher Education" (2014). The Law declared international integration, in particular, integration of the national higher education system into the European educational space, and active participation of Ukrainian universities in such programs as Erasmus + and Horizon 2020, which altogether have formed a significant segment of Ukrainian international academic mobility.

Educational migration is an integral part of the process of integrating education, science, and production: common usage of the potential of educational, scientific and industrial organizations in their mutual interest, in the first place, in the fields of training specialists, advanced training and retraining of personnel, as well as joint research, implementation of scientific developments, etc. The necessary conditions for educational migration are the capacity for educational activity, the ability and desire to carry it out; the availability of appropriate educational institutions in the country; the influence of factors in favor of educational migration outweighing the desire of staying in the country of residence.

A specific feature of educational migration, according to researchers, is that it is less harmful comparing to other types of migration. The desire of educational migration is conditioned not only by the income of the educational sector but also by the economy of the country providing the educational services as a whole. Moreover, consumers of educational services form a potential workforce of relevant qualifications. This is considered to be positive for the country-recipient of student migrants. As regards the country that loses its population, the situation is quite opposite [1].
$\mathrm{T}$ oday Ukraine is mainly a supplier of educational migrants to other countries, due to increased access to education abroad (mainly in EU countries bordering Ukraine), expanded international cooperation with Ukrainian universities, and deepened economic connections with the EU. Although the share of educational migrants in the total working population traveling abroad is insignificant (about $5 \%$ ), the impact of youth migration processes has very ambiguous consequences for the migrant supplying country.

The benefits for the country-recipient include, first and foremost, the economic benefits that result from the increase in financial revenues to the country in the form of tuition fee and, consequently, tax revenues to the state budget. The growing demand for higher education services in the countries of destination of migrants leads to expansion of the range of educational services, integration of national higher education institutions into the international educational and scientific system, growth of an innovative component of education and technical improvement of the educational process. For these countries, the influx of young people is a chance to make the population younger, intellectualize the country's human capital, fill the economy with skilled specialists, and accelerate the country's scientific, technical and economic development. Recognizing the economic benefits of converting educational migrants into skilled labor market participants, governments in developed countries are pursuing policies to assist foreign students in their future employment.

If a migrant returns home, studying abroad has a positive effect on the country of origin. In this case, the country receives a more trained specialist than the ordinary migrant worker because he/she knows the language, and the social and cultural potential obtained during the years of education gives him/her better adaptation characteristics. Studying abroad under exchange or government-funded programs within the promotion policy also creates savings in skills training for the migrant supplying country. However, the major threat posed by the student donor country is the risk of loss of its intellectual capacity, aging of the population due to the departure of the youth, and the transformation of educational migration into emigration through studying abroad, causing the brain drain phenomenon [5].

According to UNESCO, from 2000 to 2012, the number of Ukrainian students in the world increased more than four times. It grew especially rapidly in countries where labor migration flows are directed [2].

Considering the doubtful reliability of figures provided by state institutions, it is more appropriate to use the data generated by international organizations and non-governmental organizations, which take into account latent migration flows between countries and the peculiarities of migrant statistics for some of them.

To describe the current trend of student migration in Ukraine, the data were taken from the World Bank Database [10]. The series which matches this aim 
is outbound mobility ratio, number of students from a given country studying abroad as a percentage of the total tertiary enrolment in the country. Its changes during the period of 2011-2017 can be found below (Fig. 2). The figures tend to increase consistently each year. While in 2011 it was only about $1.5 \%$, in 2016 it reached the value of more than $4.5 \%$.

$\mathrm{D}$ ue to the statistical research of the analytical center CEDOS, the data about Ukrainian students abroad became widely available [6]. Therefore, this study shows that the scale of student migration is gradually increasing from year to year (Fig. 3).

In 2015 the number of students from Ukraine who went abroad was reported as almost 60000 individuals. Countries that host them are presented in Fig. 4. The top ones are Poland (42\%), Germany (17 \%), Russia (17\%). The statistics show that the number of migrating students is not stable at all - in 2015 it grew 1.3 times compared to 2009. Educational institutions in Poland tend to attract mostly Ukrainians. This fact can be explained by the advantageous geographical proximity, the ease in learning the local language, relatively cheap prices for goods and services, as well as reasonable tuition fees in universities.
Plenty of Ukrainian students among others immigrated to pursue their studies in Polish universities is $54 \%$. Belarus comes next with only $10 \%$.

In other countries, Ukrainians are inferior to other student diasporas, accounting for up to $7 \%$. For example, in Russia and Germany, Ukrainian students accounted for $6.8 \%$ and $2.9 \%$, respectively [7].

The CEDOS center prepared a report on the gender division of the shares of Ukrainians migrating with the aim to get higher education, based on the data of the 2014/2015 academic year (Fig. 5).

$\Lambda$ $\mathrm{s}$ can be seen from the figure, the number of women is significantly higher in European universities, with Italy, Austria, and Croatia being at the top. This fact is influenced by numerous factors, from the gender policies in these countries to the opportunities to find a highly paid job, which are equal for both sexes. These top-3 countries are just known for the comfortable standards of living, especially in Switzerland, which is in the $4^{\text {th }}$ place.

Gender plays an important role in analyzing the factors affecting the choice of whether to study abroad or not. Generally, women, contrary to men, pay more attention to the effect of their mobility on relations with the families left at home.

Ratio, \%

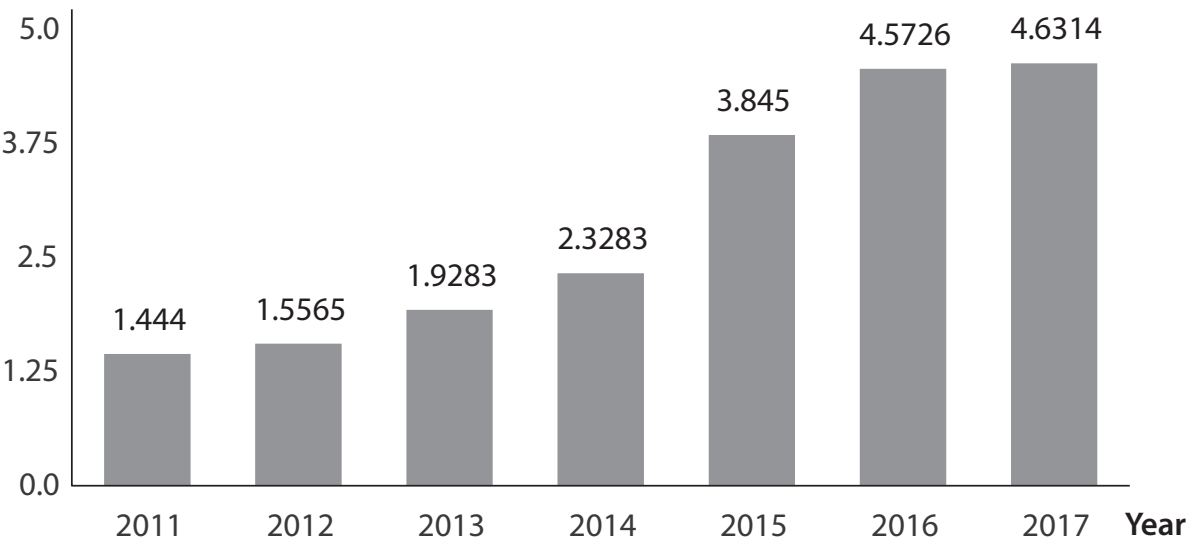

Fig. 2. Outbound mobility ratio, all regions, both sexes (\%) [10]

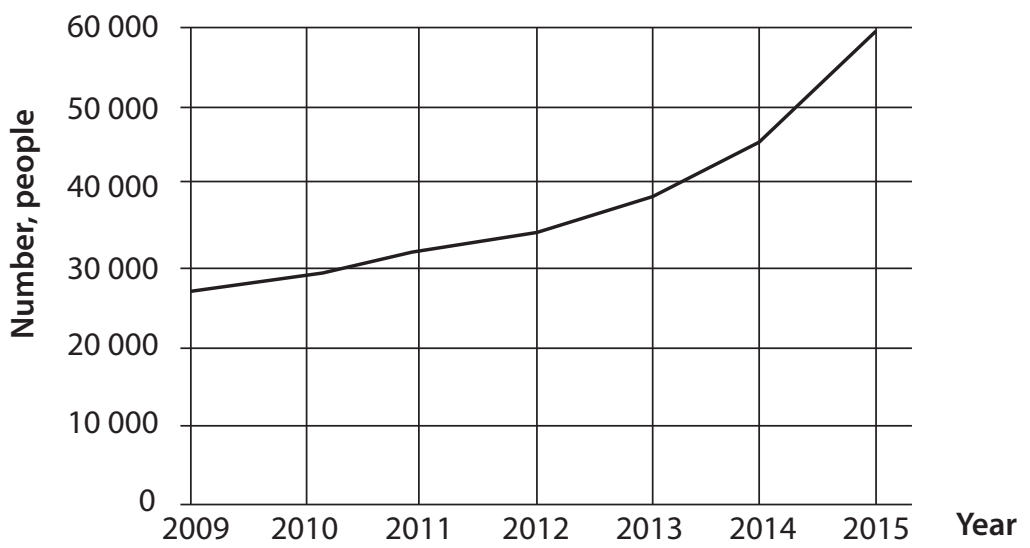

Fig. 3. The rise in the number of Ukrainian students in foreign universities [6] 


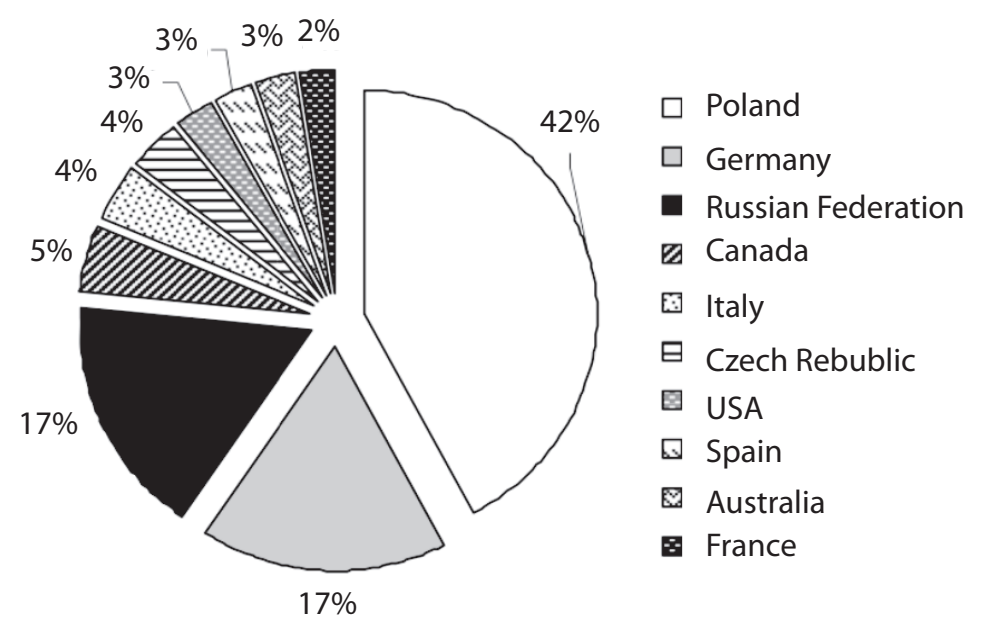

Fig. 4. Percentage of Ukrainian students studying abroad [7]

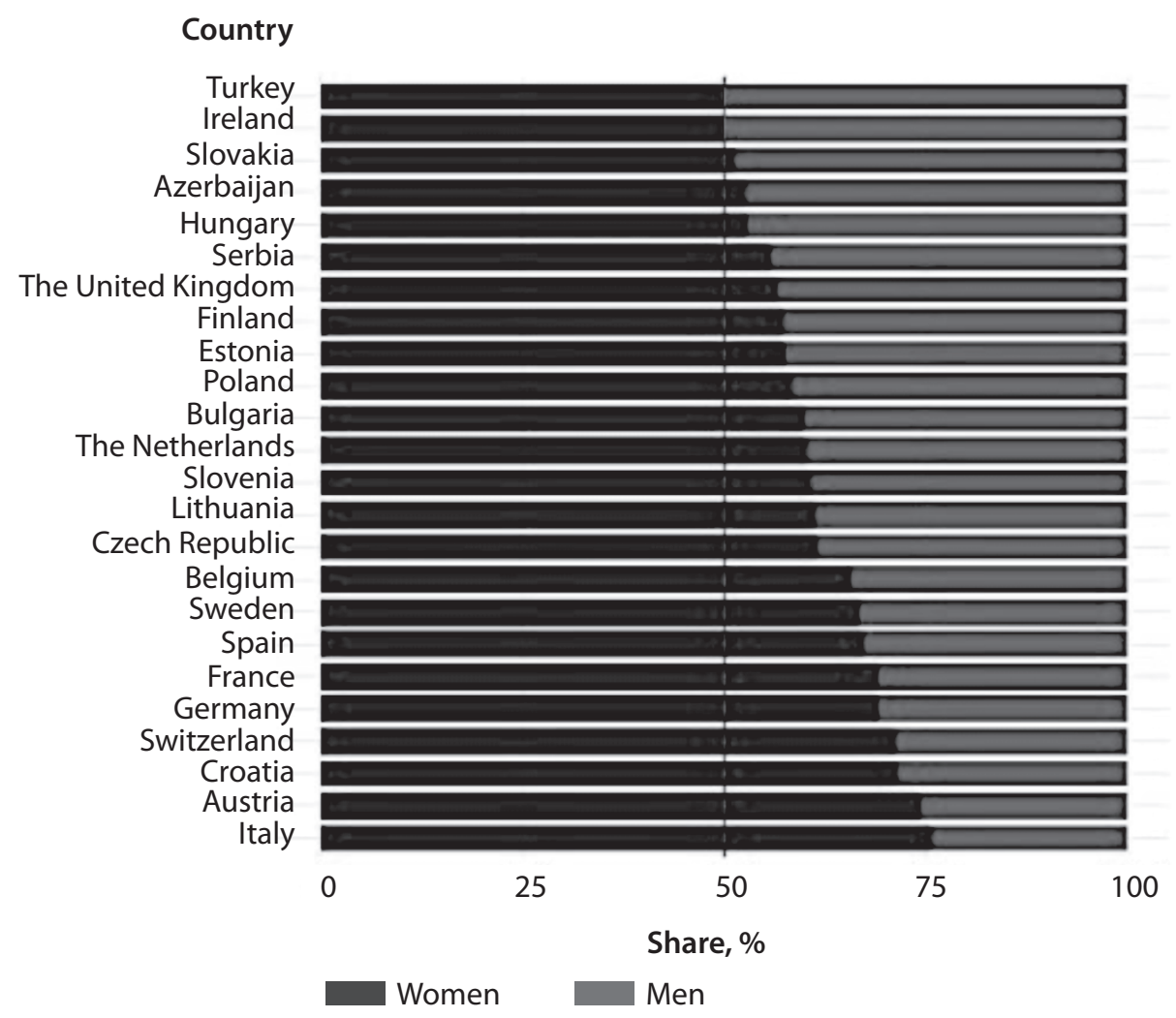

Fig. 5. Share of Ukrainians in foreign universities, women and men, 2014/1015 [6]

A lot of citizens going to study abroad are influenced by multiple factors. The reasons for choosing another country for tertiary studies include a higher level of education quality, higher wages after graduating from a university, opportunities for self-realization, chances for career development, extension of international relationships, networking, better conditions of living, etc.

$\mathrm{T}$ The human capital investment model supposes that a migrant grounds his/her choice on the costs of moving. Nevertheless, the case of student migration is slightly different because all of the funds spent on the relocation are regarded as those that can be replen- ished in the future - after graduation. Thus, they can increase one's income afterward. For this reason, student migration is possible either when there are fewer chances to get high quality higher education in the native country but there is a strong demand for professionals there, so they return home to become well-paid employee or the native society and labor market cannot provide a sufficient level of income. That is why, the youth chooses to get professional education abroad and therefore stay there for permanent residency. This is when the brain drain phenomenon emerges [8].

The majority of Ukrainian students have migrated bearing in mind the fruitful results from a foreign system 
of education, while the government of Ukraine has recently started making the tertiary education system more complex to enroll. For instance, despite the fact that each state university ought to have budget-funded places, it has become more difficult for an enrollee to show his/her level of knowledge because of obligatory exams, which are to be taken after leaving school. Moreover, to enroll the master cycle another step of independent exams has been introduced.

A nother important factor influencing choices on migration is the psychological component. Quite often, individuals tend to relocate for studies to countries that have common traditions and mentality with their native one. The ability to learn a local language without too much difficulty is also critical [6].

The impact of costs required for student migration depends on the size of these costs. Countries that provide an opportunity to study for free tend to attract Ukrainian students. For example, Ukrainians are welcomed to study without enrolment fees in France and Germany. Also, the governments of many countries where the tertiary education is fee-based for foreigners create special scholarships for this category of university students. However, they are usually offered to a small share of applicants, the most competent ones, since the funding is restrained.

It was discovered that, generally, students are not concerned about a long distance separating the country of origin and the country of destination. Nowadays lowcost air companies offer cheap flights on a regular basis, which can be a possible explanation of this fact [6].

In order to reinforce the analytical ideas, we have built a multiple regression model with the dependent variable of the outbound mobility ratio through the span of 2011-2017. The other variables included in the model are government expenditure on tertiary education, initial household funding per tertiary student, international tourism (number of departures), GDP at market prices ( $T b l .2$ ).

The results obtained with the statistical package Gretl can be found in Tbl. 3 .
Interestingly, despite the small number of observations, the only variable that shows the dependence is the volume of international tourism in Ukraine. It means that the population of the country learns more about the cultures of various nations while traveling there. Moreover, bearing in mind that the majority of the universities popular among Ukrainians are located in Europe, the facilitation of traveling (cancellation of mandatory visas on the territory of the EU) has contributed to the number of Ukrainian students going to another country with the aim of studying there.

\section{CONCLUSIONS}

The intensification of migration processes in the context of globalization is a tendency of modern international economic relations. Student migration is a complex and ambiguous process that has a significant and even remote impact on the country of origin and the country of destination. Obviously, youth migration is a very negative phenomenon. It can only be positive if the migrants return to their homeland, having received foreign education of high quality and work experience there. At the macro level, this leads to increased productivity, reduced unemployment and poverty, and accelerated economic and human development. Unfortunately, in practice, we have negative consequences in the form of emigration of educated, mobile youth who could generate national income. In addition, they are active people with formed $\mathrm{Eu}$ ropean values who could contribute to the development of their own country.

The most positive impact for all sides is student migration under academic exchange programs, which enables students to gain knowledge and cultural experience, and educational institutions - to forge international cooperation. Nevertheless, Ukraine has to take urgent measures in order to prevent the brain drain.

The measures should include the modernization of the national education system on such principles that could prove that it is really competitive in the world's educational market and provides a high level of knowledge.

Table 2

Data for multiple regression analysis on student migration in Ukraine [10]

\begin{tabular}{|c|c|c|c|c|c|}
\hline Year & $\begin{array}{c}\text { Outbound mobility } \\
\text { ratio, all regions, } \\
\text { both sexes (\%) }\end{array}$ & $\begin{array}{c}\text { Expenditure on edu- } \\
\text { cation as \% of total } \\
\text { government expen- } \\
\text { diture (\%) }\end{array}$ & $\begin{array}{c}\text { Initial household } \\
\text { funding per ter- } \\
\text { tiary student, con- } \\
\text { stant PPP\$ }\end{array}$ & $\begin{array}{c}\text { International } \\
\text { tourism, number } \\
\text { of departures }\end{array}$ & $\begin{array}{c}\text { GDP at market } \\
\text { prices (current } \\
\text { USD) }\end{array}$ \\
\hline 2011 & 1.44402 & 13.48432 & 1603.99631 & 19773000 & $1.63 \mathrm{E}+11$ \\
\hline 2012 & 1.5565 & 13.66552 & 1543.83725 & 21433000 & $1.76 \mathrm{E}+11$ \\
\hline 2013 & 1.92826 & 13.86764 & 1679.48493 & 23761000 & $1.83 \mathrm{E}+11$ \\
\hline 2014 & 2.32829 & 13.12135 & 1334.15901 & 22438000 & $1.34 \mathrm{E}+11$ \\
\hline 2015 & 3.84503 & 13.02241 & 1328.31879 & 23142000 & $9.10 \mathrm{E}+10$ \\
\hline 2016 & 4.57255 & 12.35312 & 1326.35562 & 24668000 & $9.34 \mathrm{E}+10$ \\
\hline 2017 & 4.63141 & 13.05142 & 1145.63615 & 26437000 & $1.12 \mathrm{E}+11$ \\
\hline
\end{tabular}


OLS model with the dependent variable of outbound mobility ratio, all regions, both sexes

\begin{tabular}{|c|c|c|c|c|c|}
\hline \multicolumn{6}{|c|}{ Model 1: OLS, using observations 2011-2017 ( $T=7)$} \\
\hline \multicolumn{6}{|c|}{ Dependent variable: Outboundmobilityratioallre } \\
\hline & coefficient & std. error & t-ratio & p-value & \\
\hline const & 1.50217 & 8.99861 & 0.1669 & 0.8828 & \\
\hline Expenditureonedu & -0.305169 & 0.711454 & -0.4289 & 0.7098 & \\
\hline Initialhousehold & 0.000416065 & 0.00167320 & 0.2487 & 0.8268 & \\
\hline Internationaltou & $3.31524 \mathrm{e}-07$ & $9.37524 \mathrm{e}-08$ & 3.536 & 0.0715 & * \\
\hline GDPatmarketprice & $-2.06819 e-11$ & $1.14392 \mathrm{e}-11$ & -1.808 & 0.2123 & \\
\hline Mean dependent var & 2.900866 & \multicolumn{2}{|c|}{ S.D. dependent var } & 1.407378 & \\
\hline Sum squared resid & 0.273692 & \multicolumn{2}{|c|}{ S.E. of regression } & 0.369927 & \\
\hline R-squared & 0.976970 & \multicolumn{2}{|c|}{ Adjusted R-squared } & 0.930911 & \\
\hline$F(4,2)$ & 21.21101 & \multicolumn{2}{|c|}{ P-value (F) } & 0.045529 & \\
\hline Log-likelihood & 1.413241 & \multicolumn{2}{|c|}{ Akaike criterion } & 7.173517 & \\
\hline Schwarz criterion & 6.903068 & \multicolumn{2}{|c|}{ Hannan-Quinn } & 3.830815 & \\
\hline rho & 0.326621 & \multicolumn{2}{|c|}{ Durbin-Watson } & 1.139891 & \\
\hline
\end{tabular}

Excluding the constant, p-value was highest for variable 3 (Initialhouseholdfundingpert)

Universities themselves can affect the current situation by improving management and organizational technologies of the interaction between the administration of a university and students, implementing various educational programs at the municipal and national level to attract students and, as a consequence, to decrease their migration, using the mechanism of student employment support after graduation, intensifying cooperation with graduates, etc.

\section{LITERATURE}

1. Філатов В., Ромашова Я. Специфічні ознаки освітньої міграції та її місце в структурі міграційних потоків. Ефективна економіка. 2014. № 2. URL: http:// www.economy.nayka.com.ua/?op $=1 \& z=2785$

2. Міграція в Україні: факти і цифри / Міжнародна організація з міграції (МОМ). Представництво в Українi. 2016. 31 c. URL: http://iom.org.ua/sites/default/ files/ff_ukr_21_10_press.pdf

3. Ионцев В. А. Международная миграция населения: теория и история изучения. М. : Диалог - МГУ, 1999. $370 \mathrm{c}$.

4. Малиновська О. А. Урізноманітнення складу населення України під впливом міжнародної міграції: виклик та шляхи реагування. Аналітична доповідь. Київ : НІСД, 2012. 56 c. URL: https://niss.gov.ua/sites/ default/files/2012-11/malin_dop-e2d16.pdf

5. International migration, remittances, and the brain drain / Schiff, Maurice (ed.); Ozden, Caglar (ed.) et al. Washington, DC : World Bank., 2006292 p. URL: http://documents.worldbank.org/curated/en/ 426881468127174713/International-migration-remittances-and-the-brain-drain
6. Слободян О., Стадний Є. Українські студенти за кордоном: скільки та чому? 13.12.2016. URL: https:// cedos.org.ua/uk/articles/ukrainski-studenty-zakordonom-skilky-ta-chomu

7. Ситник О. Взаємодія роботодавців та вищих навчальних закладів в контексті стабілізації освітніх міграційних потоків. Наукові праці Кіровоградського національного технічного університету. Серія «Економічні науки». 2017. Вип. 32. С. 123-131. URL: http://dspace.kntu.kr.ua/jspui/bitstream/ 123456789/7466/1/14.pdf

8. Величко К. Ю., Носач Л. Л., Печенка О. І. Міграційні процеси в Україні: сучасні тенденції та соціальноекономічні наслідки. Економічна стратегія і перспективи розвитку срери торгівлі та послуг. 2017. Вип. 2. С. 232-246. URL: http://elib.hduht.edu.ua/ bitstream/123456789/2191/1/ек.3_5сек.\%20Величко\%20та\%20інші.pdf

9. Чоловіки та жінки / Демографічна та соціальна статистика / Населення та міграція // Державна служба статистики України. URL: http://www.ukrstat.gov.ua/ operativ/menu/menu_u/ds.htm

10. World Bank Open Data // The World Bank official website. URL: https://data.worldbank.org

\section{REFERENCES}

"Choloviky ta zhinky / Demohrafichna ta sotsialna statystyka / Naselennia ta mihratsiia" [Men and Women / Demographic and Social Statistics / Population and Migration]. Derzhavna sluzhba statystyky Ukrainy. http:// www.ukrstat.gov.ua/operativ/menu/menu_u/ds.htm

Filatov, V., and Romashova, Ya. "Spetsyfichni oznaky osvitnyoi mihratsii ta yii mistse v strukturi mihratsiinykh potokiv" [Specific Features of Educational Migration and its Place in the Structure of Migration Flows]. Efek- 
tyvna ekonomika. 2014. http://www.economy.nayka. com.ua/?op $=1 \& z=2785$

"International migration, remittances, and the brain drain". http://documents.worldbank.org/curated/en/ 426881468127174713/International-migration-remittances-and-the-brain-drain

lontsev, B. A. Mezhdunarodnaya migratsiya naseleniya: teoriya i istoriya izucheniya [International Population Migration: Theory and History of Study]. Moscow: Dialog MGU, 1999.

"Mihratsiia v Ukraini: fakty i tsyfry" [Migration in Ukraine: Facts and Figures]. Mizhnarodna orhanizatsiia z mihratsii (MOM). Predstavnytstvo v Ukraini. 2016. http:// iom.org.ua/sites/default/files/ff_ukr_21_10_press.pdf

Malynovska, O. A. "Uriznomanitnennia skladu naselennia Ukrainy pid vplyvom mizhnarodnoi mihratsii: vyklyk ta shliakhy reahuvannia. Analitychna dopovid" [Diversification of the Population of Ukraine under the Influence of International Migration: Challenge and Ways of Response. Analytical Report]. https://niss.gov.ua/ sites/default/files/2012-11/malin_dop-e2d16.pdf

Slobodian, O., and Stadnyi, Ye. "Ukrainski studenty za kordonom: skilky ta chomu?" [Ukrainian Students Abroad:
How Many and Why?]. 13.12.2016. https://cedos. org.ua/uk/articles/ukrainski-studenty-za-kordonomskilky-ta-chomu

Sytnyk, O. "Vzaiemodiia robotodavtsiv ta vyshchykh navchalnykh zakladiv $v$ konteksti stabilizatsii osvitnikh mihratsiinykh potokiv" [Interaction between Employers and Higher Education Institutions in the Context of Stabilization of Educational Migration Flows]. Naukovi pratsi Kirovohradskoho natsionalnoho tekhnichnoho universytetu. Seriia «Ekonomichni nauky». 2017. http://dspace.kntu.kr.ua/jspui/bitstream/123456789/7466/1/14.pdf

Velychko, K. Yu., Nosach, L. L., and Pechenka, O. I. "Mihratsiini protsesy $v$ Ukraini: suchasni tendentsii ta sotsialno-ekonomichni naslidky" [Migration Processes in Ukraine: Contemporary Trends and Socio-Economic Consequences]. Ekonomichna stratehiia i perspektyvy rozvytku sfery torhivli ta posluh. 2017. http:// elib.hduht.edu.ua/bitstream/123456789/2191/1/ ек.3 5сек.\%20Величко\%20та\%20інші.pdf

"World Bank Open Data". The World Bank official website. https://data.worldbank.org

\section{РЕЙТИНГОВІ СИСТЕМИ ОЦІНЮВАННЯ БІЗНЕС-СЕРЕДОВИЩА ПРИЙМАЮЧОЇ КРАЇНИ ๑ 2020 КАЛЮЖНА Н. Г., ЛЕЖЕПЬОКОВА В. Г.}

УДК 339.977

JEL: F23

Калюжна Н. Г., Лежепьокова В. Г. Рейтингові системи оцінювання бізнес-середовища приймаючої країни

Статтю присвячено аналізу міжнародних рейтингів та індексів, що розробляються провідними міжнародними установами й організаціями $з$ метою дослідження різних аспектів розвитку країни. Охарактеризовано ключові рейтингові системи, які дозволяють оиінити ступень сприятливості бізнес-середовища приймаючої країни для здійснення підприємницької діяльності, виокремлено їх складові та параметри оцінки. Зазначено країни-лідери та позиції України в рейтингах індексів економічної свободи, глобальної конкурентоспроможності, легкості ведення бізнесу та залучення країн до міжнародної торгівлі. Показано, що міжнародні рейтингові системи створюють широкі можливості для аналізу бізнессередовища функціонування географічно диверсифікованих міжнародних компаній. Обгрунтовано, що розмаїття підходів до оцінювання та використовуваних індикаторів зумовлює проблематичність зіставлення результатів використання рейтингових систем і визначає доцільність подальших розвідок у напрямі вдосконалення інструментарію оцінювання сприятливості бізнес-середовища приймаючої країни. 3 метою зниження суб'єктивності та забезпечення комплексності результату запропоновано підхід до розрахунку агрегованого показника, що дозволяє оцінити сприятливість національного середовища для міннародного бізнесу за його визначальними складовими.

Ключові слова: рейтингування економічних процесів, індекс економічної свободи, індекс глобальної конкурентоспроможності, індекс легкості ведення бізнесу, індекс залучення країн до міжнародної торгівлі, агрегований показник оцінювання сприятливості бізнес-середовища країни. DOl: $h$ ttps://doi.org/10.32983/2222-4459-2020-5-70-78

Рис.: 4. Табл.: 1. Формул: 1. Бібл.: 14.

Калюжна Наталія Геннадіївна - доктор економічних наук, доцент, професор кафедри світової економіки, Київський національний торговельноекономічний університет (вул. Кіото, 19, Київ, 02156, Україна)

E-mail: kalujnaya.natalya@gmail.com

ORCID: http://orcid.org/0000-0003-0513-705X

Researcher ID: https://publons.com/researcher/2229717/nataliya-g-kalyuzhna/

Лежепьокова Вікторія Геннадіївна - кандидат економічних наук, доцент, доцент кафедри світової економіки, Київський національний торговельно-економічний університет (вул. Кіото, 19, Київ, 02156, Україна)

E-mail: v.lezhepokova@knute.edu.ua

ORCID: http://orcid.org/0000-0003-4253-6885

Researcher ID: https://publons.com/researcher/1688019/viktoriia-lezhepokova/

УДК 339.977

JEL: F23

Калюжная Н. Г., Лежепёкова В. Г. Рейтинговые системы оценки бизнес-среды принимающей страны Статья посвящена анализу международных рейтингов и индексов, которые разрабатываются ведущими международными учреждениями и организациями с иелью исследования разных аспектов развития страны. Охарактеризованы ключевые рейтинговые системы, которые позволяют оценить степень привлекательности бизнес-среды принимающей страны для осуществления предпринимательской деятельности, выделены их составляющие и параметры оценки. Определены страны-лидеры и позиции Украины в рейтингах индексов экономической свободы, 